\title{
Karizmatska obilježja Franje Tuđmana - analiza dnevničkih zapisa (1982.-1984.)
}

Jakov Žižić*

jakov.zizic@unicath.hr https://doi.org/10.31192/np.17.1.3

UDK: 32-051Tuđman, F.

(093.3)

Izvorni znanstveni rad / Original scientific paper

Primljeno: 23. srpnja 2018.

Prihvaćeno: 30. prosinca 2018.

U ovom radu istražuje se postojanje karizmatskih obilježja kod Franje Tuđmana u razdoblju prije njegova dolaska na dužnosti predsjednika Hrvatske demokratske zajednice (HDZ) i predsjednika Republike Hrvatske. Autor analizira Tudmanove dnevničke zapise nastale tijekom njegova boravka u zatvoru od 1982. do 1984. ispitujući je li Tudman u spomenutom razdoblju iskazivao konstitutivna obilježja karizme - uvjerenje o posjedovanju posebnog dara te življenje za svoju stvar $i$ slijeđenja svog djela. Analizom dnevničkih zapisa takoder se nastoji ustanoviti je li Tuđman iskazivao i konstitutivna obilježja »čiste karizme« vjerovanje u vlastitu misiju i usmjerenost vlastite misije na odredenu skupinu ljudi. Provedena analiza pokazuje da je u razmatranom razdoblju Tudman iskazivao karizmatska obilježja koja će biti važna pretpostavka razvoja njegova karizmatskog vodstva početkom 1990-ih.

Ključne riječi: karizma, Franjo Tudman, Hrvatska demokratska zajednica, osobni dnevnik.

* Jakov Žižić, magistar politologije i doktorand komparativne politike na Fakultetu političkih znanosti u Zagrebu; asistent na Hrvatskom katoličkom sveučilištu, Ilica 242, HR-10000 Zagreb. 


\section{Uvod}

Karizma Franje Tuđmana zauzima nezaobilazno mjesto u objašnjavanju i razumijevanju hrvatske politike u posljednjem desetljeću 20. stoljeća. Tuđmanova karizma ima osobitu važnost u kontekstu njegove uloge u Hrvatskoj demokratskoj zajednici (HDZ) koja se nakon osnivanja 1989. oblikovala kao široki nacionalni pokret za hrvatsku državnu samostalnost. Tuđman je unutar ovog pokreta vrlo brzo stekao status »nedodirljivog« karizmatskog vođe s gotovo mesijanskim značenjem za svoje sljedbenike. ${ }^{1}$ Razvoj Tuđmanove karizme početkom 1990-ih bio je uvelike uvjetovan tadašnjim kontekstom ubrzanih društvenih promjena unutar rastuće krize u jugoslavenskoj federaciji. ${ }^{2}$ Neki ističu Tuđmanov status karizmatskog vođe unutar HDZ-a i širokog nacionalnog pokreta za hrvatsku državnu samostalnost, no nitko od njih ne ulazi u sustavna istraživanja razvoja Tuđmanova karizmatskog vodstva. ${ }^{3}$

Istraživanjem karizme Franje Tuđmana dosad se najsustavnije bavio Robert Blažević koji je Tuđmanovu karizmu doveo u vezu s njegovom stigmom, sagledavajući ih u paru, kao dva pola jednog fenomena. ${ }^{4}$ Blažević ističe da je u komunističkoj Jugoslaviji Tuđman bio stigmatiziran i negativno obilježen kao nacionalist i politički kriminalac. Nakon sloma komunističke Jugoslavije i korjenite promjene političkog i društvenog konteksta stvaranjem samostalne $\mathrm{Hr}$ vatske, Tuđmanova stigma nacionalista poprima pozitivno obilježje i pretvara se u karizmu nacionalnog borca. ${ }^{5} \mathrm{U}$ svom istraživanju Blažević se uglavnom bavi razvojem i percepcijom Tuđmanove karizme na njezinu vrhuncu tijekom 1990-ih kada je Tuđman obnašao dužnosti predsjednika države i predsjednika HDZ-a, te pritom ne ulazi u analizu Tuđmanove karizme prije njegova dolaska na spomenute dužnosti.

Teoretičar karizmatskog vodstva Robert C. Tucker smatra da je karizmu nužno istraživati prije dolaska na političku dužnost jer, ukoliko neki pojedinac uistinu ima karizmatsku osobnost, ona će se početi pokazivati i prije zadobivanja formalne političke moći. ${ }^{6}$ Istraživanjem karizme prije dolaska na dužnost izbjegava se mogućnost da se njezin utjecaj pripiše formalnoj političkoj

${ }^{1}$ Usp. Goran ČULAR, Political Development in Croatia 1990-2000. Fast Transition - Postponed Consolidation, Politička misao, 37 (2000) 5, 30-46, 35.

2 Usp. Čular, Political Development..., 35-36.

${ }^{3}$ Primjerice, Dario NIKIĆ ČAKAR, Prezidencijalizacija političkih stranaka. Komparativna analiza britanske Laburističke stranke, Španjolske socijalističke radničke stranke i Hrvatske demokratske zajednice, Zagreb, Fakultet političkih znanosti, 2013, 203; Davor BOBAN, Changes in the system of government and consolidation of democracy. A comparison of the role of president in Croatia and Slovakia. Studia lexicographica, 10 (2017) 1, 151-172, 163.

${ }^{4}$ Usp. Robert BLAŽEVIĆ, Karizma. Politička vlast i karizmatske ličnosti, Rijeka, Pravni fakultet Sveučilišta u Rijeci, 2006, 153-154.

${ }^{5}$ Usp. Blažević, Karizma..., 268-284.

${ }^{6}$ Usp. Robert C. TUCKER, The Theory of Charismatic Leadership, Daedalus, 97 (1968) 3, 731 756, 740. 
moći koja je povezana s obnašanjem neke dužnosti. Predmet ovog rada bit će stoga istraživanje Tuđmanove karizme u razdoblju prije dolaska na dužnosti predsjednika HDZ-a i predsjednika Republike Hrvatske. Da bi se ustanovilo je li Tuđman iskazivao obilježja karizme prije dolaska na spomenute dužnosti, analizirat će se dio njegova osobna dnevnika koji se odnosi na razdoblje provedeno u zatvoru od 1982. do 1984. godine. ${ }^{7}$ U navedenom razdoblju Tuđman je najiscrpnije pisao svoj dnevnik i stoga su odabrane dnevničke bilješke najreprezentativnije za ispitivanje postojanja obilježja karizme. U prvom dijelu rada autor će izložiti porijeklo, značenje i ključna obilježja pojma karizma. U drugom dijelu rada analizirat će se odabrani Tuđmanovi dnevnički zapisi i iščitavati prisutnost obilježja karizme. Na kraju će autor dati zaključni osvrt na postojanje Tuđmanovih karizmatskih obilježja u analiziranom razdoblju i njihov utjecaj na razvoj Tuđmanova karizmatskog vodstva početkom 1990-ih.

\section{Porijeklo i značenje pojma karizme}

Riječ karizma (grč. »hárisma« - milost, nezasluženi dar) prvo se počela koristiti u kršćanskoj teologiji. ${ }^{8}$ Za svetog Pavla karizma je značila dar Božje milosti koji osposobljuje pojedinca za neku funkciju u kršćanskoj zajednici. Prema njemu, raznolikost darova, sposobnosti i talenata potječe iz jedinstva Duha Svetoga kao njihova izvora, s jedne, te iz raznovrsnosti funkcija i potreba kojima zajednica mora udovoljiti da bi proširila istinu, s druge strane. ${ }^{9}$ Pojam karizme izvorno je stvorio njemački pravnik i crkveni povjesničar Rudolf Sohm povezujući ga s darom milosti, duhom koji ima religijski nadahnuti pojedinac. ${ }^{10}$ Za široku primjenu i popularnost pojma karizme najzaslužniji je njemački sociolog Max Weber koji je karizmu uključio u svoju poznatu tipologiju vlasti označivši je kao jedan od triju načina na koje vlast temelji svoj legitimitet.

Prema Weberu postoje tri temelja legitimnosti vlasti - tradicionalni, legalno-racionalni i karizmatski. Tradicionalna vlast počiva na svetosti tradicije, običaja i onog što je uvijek tako bilo i što propisuje poslušnost prema određenim osobama. ${ }^{11}$ Povijesni primjeri tradicionalne vlasti su patrijarsi takozvanih tra-

\footnotetext{
7 Objavljeni dnevnici političara su jedan od najvažnijih izvora u politološkim istraživanjima, a u proučavanju karizme imaju osobitu važnost jer mogu pružiti uvid u život i djelovanje političara prije dolaska na dužnost (usp. Peter BURNHAM i dr., Metode istraživanja politike, Zagreb, Fakultet političkih znanosti Sveučilišta u Zagrebu, 2006, 181-183 i Tucker, The Theory of Charismatic Leadership..., 747).

${ }^{8}$ Usp. Blažević, Karizma..., 7.

9 Usp. Jean-Claude MONOD, Što je vođa u demokraciji? Politike karizme, Zagreb, TIM Press, 2014, 29.

${ }^{10}$ Usp. Joseph BENSMAN, Michael GIVANT, Charisma and Modernity. The Use and Abuse of a Concept, Social Research, 42 (1975) 4, 570-614, 571.

${ }^{11}$ Usp. Max WEBER, Vlast $i$ politika, Zagreb, Naklada Jesenski i Turk - Hrvatsko sociološko društvo, 2013, 72.
} 
dicionalnih društava, seoski »mudraci«, feudalni zemljoposjednički »vazali«. ${ }^{12}$ Legalno-racionalna vlast se temelji na racionalnim, apstraktnim i općeobvezujućim pravnim normama. U ovom tipu vlasti poslušnost se obavlja radi pravila, a ne radi osobe. ${ }^{13}$ Najčistiji tip legalno-racionalne vlasti je birokratska vlast (birokracija), odnosno racionalna uprava. ${ }^{14}$ Karizmatska vlast se temelji na vjerovanju u nesvakidašnji osobni dar milosti (karizmu) koji pojedincu daje karakter vođe. ${ }^{15}$ Nesvakidašnjost i iznimnost vođe može biti magičnog, proročanskog, junačkog ili ratničkog podrijetla ili naprosto povezana s umijećem javnog nastupa, osobnom, fizičkom ili moralnom »aurom «. ${ }^{16}$ Kao primjere karizmatske vlasti Weber navodi proroka, izabranog ratnog vođu, plebiscitarnog vladara, velikog demagoga i vođu političke stranke. Predanost karizmi proroka, ili vođe u ratu ili velikog demagoga u Crkvi ili parlamentu, znači da je on osobno priznat za nekog tko je iznutra "pozvan « za vođu, da mu se ljudi ne priklanjaju radi običaja ili norme, nego zato što vjeruju u njega. ${ }^{17}$

\section{Ključna obilježja karizme}

Karizmatsko vodstvo najčešće nastaje u situacijama krize kada su dovedene u pitanje temeljne vrijednosti, institucije i legitimnost društva. ${ }^{18} \mathrm{U}$ kriznim okolnostima stvara se potreba za karizmatskim vodstvom koje je specifično spasiteljsko ili mesijansko u svojoj prirodi. ${ }^{19}$ Karizmatsko vodstvo je jedinstven osobni odgovor na krizu zajednice, za razliku od »svakodnevne rutine « legalne i tradicionalne vlasti. ${ }^{20}$ Za karizmu nije ključno posjedovanje posebnog dara per se, već neupitno vjerovanje - kako sljedbenika tako i vođe - da vođa ima poseban dar. ${ }^{21}$ Prema Weberu, karizmatični vođa je onaj koji živi za svoju stvar i »ide za svojim djelom «, te ako je nešto više od trenutnog ograničenog i sujetnog skorojevića. ${ }^{22}$

Weber razlikuje »čistu karizmu« (osobnu karizmu) i »rutiniziranu karizmu« (karizmu funkcije). Čista karizma jest poziv, misija ili duhovna dužnost te je antiekonomska, odnosno odbacuje svakodnevnu rutinu. ${ }^{23}$ Čista karizma se po-

\footnotetext{
${ }^{12}$ Usp. Monod, Što je vođa u demokraciji?..., 31.

${ }^{13}$ Usp. Weber, Vlast i politika..., 71-72.

${ }^{14}$ Usp. Blažević, Karizma..., 51.

${ }^{15}$ Usp. Weber, Vlast i politika..., 185.

${ }^{16}$ Usp. Monod, Što je vođa u demokraciji?..., 32.

${ }^{17}$ Usp. Weber, Vlast i politika..., 186.

${ }^{18}$ Usp. Bensman, Givant, Charisma and Modernity..., 573

${ }^{19}$ Usp. Tucker, The Theory of Charismatic Leadership..., 743.

${ }^{20}$ Usp. Blažević, Karizma..., 58.

${ }^{21}$ Usp. Bensman, Givant, Charisma and Modernity..., 571.

${ }^{22}$ Usp. Weber, Vlast i politika..., 186.

${ }^{23}$ Usp. Goran MILJAN, »Karizmatični« Poglavnik? Poglavnik i formiranje karizmatske zajednice - primjena i korisnost Weberova koncepta karizme, Historijski zbornik, 66 (2013) 1, 121-147,
} 
javljuje u izvanrednim i kriznim okolnostima i vodi, barem privremeno, prema djelovanju, pokretima, događajima i organizacijama koji su izvan svakodnevne rutine. ${ }^{24}$ Čisto karizmatsko vodstvo je revolucionarno u smislu da ulazi u sukob s postojećim poretkom i delegitimira uspostavljene institucije i organizacije. U čistoj karizmi je zahtjev za pokornosti strogo osoban i temelji se na sposobnosti vođe da kod sljedbenika stvori osjećaj vjere, odanosti i pokornosti poruci koju je on izravno primio zahvaljujući svojim natprirodnim moćima. ${ }^{25}$ Važno je obilježje čiste karizme da njezin nositelj preuzima zadaću koja mu je dodijeljena i na temelju svoje misije zahtijeva od drugih da mu se pokoravaju i slijede ga. Misija karizmatika može se usmjeriti, po svom smislu i sadržaju, na grupu ljudi koja je ograničena lokalno, etnički, društveno, politički ili profesijski. ${ }^{26}$

Weber smatra da se čisti tip karizme nalazi samo u svojoj početnoj fazi, te kasnije on postaje ili tradicionalan ili racionaliziran. ${ }^{27}$ Promjena karaktera karizme podrazumijeva njezinu rutinizaciju. Da bi sljedbenici bili u mogućnosti i dalje obavljati svoju dužnost, oni traže institucionaliziranje karizme kao takve, bilo kroz posjedovanje stanovitih kvaliteta viđenih kao važnih i specifičnih značajki karizmatičnog vođe, bilo kroz ritualne manifestacije, imenovanjem, nasljeđivanjem ili karizmom ureda. ${ }^{28}$ Institucionalizacijom, odnosno "procesom obezličenja«, karizma prestaje biti osobna, izravna, radikalna, revolucionarna i izvanredna te se može vezati uz javnu dužnost i njezin nositelj može biti svaki onaj tko obavlja tu dužnost. ${ }^{29}$ Prolazeći kroz proces institucionalizacije karizma postaje depersonalizirana, i još važnije, vezivanjem uz javnu dužnost u postojećem političkom, vojnom ili religijskom poretku nestaje i njezin radikalizam. U takvim okolnostima natprirodnost ili milost karizme može postati izvor legitimnosti samog poretka. ${ }^{30}$

U skladu s izloženim teorijskim saznanjima, u ovom će istraživanju pojam karizme biti obrađen putem dva konstitutivna obilježja - a) vjerovanje u posjedovanje posebnog dara i b) življenje za svoju stvar i slijeđenje svog djela. S obzirom da će se istraživati i moguća prisutnost čiste karizme kod Franje Tuđmana, ovaj pojam će također biti promatran u dva konstitutivna obilježja - a) vjerovanje u vlastitu misiju i b) usmjerenost vlastite misije na određenu skupinu ljudi. U istraživanju će biti korištena metoda kvalitativne analiza sadržaja.

125.

${ }^{24}$ Usp. Bensman, Givant, Charisma and Modernity..., 575.

${ }^{25}$ Usp. isto, 577.

${ }^{26}$ Usp. Blažević, Karizma..., 58.

${ }^{27}$ Usp. Miljan, »Karizmatični« Poglavnik?...,125.

${ }^{28}$ Usp. isto, 125.

${ }^{29}$ Usp. Bensman, Givant, Charisma and Modernity..., 576.

${ }^{30}$ Usp. Bensman, Givant, Charisma and Modernity..., 576. 


\section{Dnevnik Franje Tudmana}

Franjo Tuđman počeo je voditi osobni dnevnik 11. siječnja 1972. nakon što je uhićen pod optužbom za »nacionalističku kontrarevoluciju«. Dnevnik je nastavio redovito pisati sve do 31. prosinca 1989. kada je već postao predsjednik netom osnovane Hrvatske demokratske zajednice. ${ }^{31} \mathrm{U}$ tom razdoblju Tuđman je na tankom papiru formata A5 zapisao 10.180 stranica dnevničkih bilješki. ${ }^{32}$ Tuđmanov dnevnički opus objavljen je u četiri knjige - dnevnik iz 1972. godine objavljen je zasebno 2003., dok su dnevnički zapisi od 1973. do 1989. objavljeni u tri povezane knjige 2011.

Dnevničke bilješke Franje Tuđmana od 1972. do 1989. donose njegovo svjedočanstvo o osobnoj sudbini, intelektualnim i moralnim dilemama, odgovornosti prema obitelji, pravim i prividnim prijateljstvima, osobnim motivima, ambicijama i ciljevima. ${ }^{33}$ Upravo stoga što donosi osobno svjedočanstvo o motivima, ambicijama i ciljevima koji ga pokreću, Tuđmanov dnevnik zahvalan je za istraživanje i razumijevanje njegovih mogućih karizmatskih obilježja. Tuđman je svoj dnevnik najiscrpnije pisao tijekom zatvorskih godina (1972., 1982.-1984.) i ova će se analiza usmjeriti na njegove dnevničke bilješke pravljene u zatvoru od 1982. do 1984.

\section{Analiza dnevničkih zapisa Franje Tuđmana (1982.-1984.)}

Franjo Tuđman je prvi put suđen 1972. kada je zbog »napada na državno i društveno uređenje « komunističke Jugoslavije osuđen na dvije godine zatvora. Odmah po izricanju presude bio je pušten iz pritvora, a kasnije mu je kazna smanjena na devet mjeseci, koliko je i proveo u pritvoru. Drugi put je Tuđmanu suđeno 1981. kada je osuđen na tri godine zatvora zbog »neprijateljske propagande «. ${ }^{34} \mathrm{U}$ siječnju 1982. Tuđman je upućen u KPD Lepoglava na izdržavanje trogodišnje zatvorske kazne. Razmišljajući o svom životu, Tuđman na 108. dan odsluženja kazne (29. travnja 1982.) bilježi u dnevnik:

»Proučavajući ponovno i ponovno svu svoju prošlost - do ovog ukletog mjesta, bi li se odrekao baš onog što te usudno vodilo ovamo?! Svakako ne. To je nedvojbeno bitniji, vredniji dio mog bivstvovanja. Odreći se istine za kojom si pošao značilo bi odreći se sama sebe. Lišen svega, čovjek zapravo postaje svjesniji baš

\footnotetext{
${ }^{31}$ Tuđman je tek sredinom 1990-tih obnovio pisanje dnevnika, no dnevnički zapisi su bili neredoviti (usp. Miroslav TUĐMAN, Na marginama Dnevnika dr. Franje Tuđmana (1973.-1989.), u: Ankica TUĐMAN (ur.), Osobni dnevnik. 1973.-1989., knj. I. (1973.-1978.), Zagreb, Večernji edicija, 2011, 9-22, 9.

${ }^{32}$ Usp. isto, 10.

${ }^{33}$ Usp. isto.

${ }^{34}$ Tuđman je zatvorsku kaznu izdržavao u KPD Lepoglava od 12. siječnja 1982. do 23. veljače 1983. te u zatvorskoj bolnici u Zagrebu od 26. svibnja do 24. kolovoza 1984.
} 
tih vrednota. I u njima nalazi spoznaje spokoja, mira, čak i radosti patnje, za koje, očito, većina nije kadra po svom sustavu, ni spremna po svom shvaćanju života. $\ll^{35}$

Sagledavajući svoj život Tuđman iskazuje odlučnost da živi za svoju stvar i slijedi svoje djelo jer »odreći se istine za kojim si pošao značilo bi odreći se sama sebe«. ${ }^{36}$ Tuđman iskazuje i uvjerenje da posjeduje poseban dar ističući da u svojoj borbi »nalazi spoznaje spokoja, mira, čak i radosti patnje, za koje, očito, većina nije kadra po svom sustavu, ni spremna po svom shvaćanju života«.37

U još jednoj dnevničkoj raščlambi svog života na svoj 113. dan u zatvoru (4. svibnja 1982.) Tuđman iskazuje vjerovanje u vlastitu misiju ističući:

»Jamačno, moj put bio je predodređen usudom osobnog poziva. I značaja. (U hrv. značenju te riječi.) I vjerom, prema onoj iz Bhagavad Gite, tog hinduskog evanđelja: »onaj tko zaista izvršava svoje dužnosti polučit će ono što očekuje. ${ }^{38}$

Svoj 60. rođendan Tuđman provodi u zatvoru što ga je nagnalo na podrobno promišljanje o životnom putu. Tako 14. svibnja 1982. piše u dnevnik:

»Ovo razapinjanje na križ robijanja, na svoj je način gore od fizičkog umorstva. Ali ta strahota nosi u sebi i inkarnaciju mučeništva u nove osobne i povijesne vrednote (...) Svaka nesebična žrtva pro patria nikad nije bila uzaludna. Njen viši smisao dobiva na značenju s vremenom (...) Na iznimnom životnom putu kojim sam pošao, vođen svojim usudom, patnje su bile neizbježive. Tragično je za mene što me prate i u ove pozne godine (...) To je cijena koja se plaća kad se svoja zvijezda vodilja slijedi iz čista srca, iz uvjerenje, bez proračuna. Kao dosljedan sljedbenik ideje o slobodi i istini svog naroda, možda i iskupljenih svojih mladenačkih zabluda, nužno sam u ovakvim prilikama morao postati zarobljenik i zatočenik filistarskih nepodopština, birokratskog farizejstva i dogmatskog karijerizma. « ${ }^{39}$

Tuđman otkriva na koga se odnosi njegova misija ističući »kako svaka nesebična žrtva pro patria nikad nije bila uzaludna « ${ }^{40}$ i predstavljajući se »kao dosljedan sljedbenik ideje o slobodi i istini svog naroda «. ${ }^{41}$ Iskazuje i uvjerenje u vlastitu misiju ističući: »Na iznimnom životnom putu kojim sam pošao, vođen svojim usudom, patnje su bile neizbježive. « ${ }^{42}$ Tuđman jasno očituje i življenje za svoju stvar i slijeđenje svog djela:

»Da nisam bio spreman trpjeti za svoja uvjerenja, mogao sam otići u inozemstvo, kao profesor, pisac, analitičar u neki institut. Od toga me odvratila spo-

\footnotetext{
${ }^{35}$ Franjo TUĐMAN, Osobni dnevnik. 1973.-1989., knj. II. (1979.-1983.), Zagreb, Večernji edicija, 2011, 252.

${ }^{36}$ Isto.

${ }^{37}$ Isto.

${ }^{38}$ Isto, 255.

${ }^{39}$ Isto, 262.

${ }^{40}$ Isto.

${ }^{41}$ Isto.

${ }^{42}$ Isto.
} 
znaja: sudba ovog naroda rješava se na domovinskom tlu... Je li moj put i ovdje mogao biti drugačiji? Nije, ako nisam htio iznevjeriti krv svog oca i najdublje osobne spoznaje. « ${ }^{43}$

Istog dana Tuđman još bilježi u dnevnik:

»Iz generalsko-profesorsko-direktorskih vrhova svjesno sam pošao neizvjesnim putem iskanja povijesna istine i pisanja o njenoj svrsi, kao dokaz žive luči u hrvatskom narodu da o svojoj sudbi sam govori kao dokaz što će sve činiti Hrvati dok sloboda ne postane njihovom svakodnevnicom. (...) U stvarnosti sve se svodilo na to da se izgnaju magle s hrvatskog tla i pohrvate hrvatska obzorja u najplemenitijem smislu... U svrhu što bezbolnijeg, povijesnog kretanja. Liječenje golemih rana prošlosti. A protiv njihova produbljivanja. U tom nastojanju bio sam poprilično osamljen. Doduše ne sam. Bili su tu na svoj način Ivo $^{44}$ i Veco, ${ }^{45}$ Kole $^{46}$ i Šibl, ${ }^{47}$ Krleža i njegov krug, ali uglavnom dok smo imali vjetar u krmu... (...) Spoznaja imperativa vremena: ako zaista želite slobodu ljudsku, nacionalnu - valja je uzeti. Vlastitim naporima. (...) Pri tom mi nije padalo na um da postanem nekakva povijesna ličnost. Želio sam biti na visini svog poziva. Svog životnog puta... (...) Nije bilo bitno: hoću li doseći plodove. Bit je u smislu. A zadovoljstvo $u$ ispravnosti, pravednosti čina. U radoznalosti ishoda i pod cijenu tragičnosti napora (...) I sve kobnosti posljedica i po mene i najbliže (...) Povijesna nužnost. Nekome je bila suđena i takva uloga u misteriju povijesti, koja se nikad ne može objasniti samo racionalnim činiteljima, pa ni spoznatljivim porivima. ${ }^{48}$

Tuđman još jednom naglašava usmjerenost svoje misije ističući da je njegovo traganje za povijesnom istinom i pisanje o njezinoj svrsi, »dokaz žive luči u hrvatskom narodu da o svojoj sudbi sam govori kao dokaz što će sve činiti Hrvati dok sloboda ne postane njihovom svakodnevnicom «. ${ }^{49}$

Tuđman dodatno iskazuje življenje za svoju stvar i slijeđenje svog djela i naposljetku očituje i vjerovanje u vlastitu misiju tvrdeći da je to povijesna nužnost. Razmatrajući uzroke trenutnih životnih okolnosti, Tuđman na svoj 137. dan izdržavanja kazne u KPD Lepoglavi (28. svibnja 1982.) zapisuje u dnevnik:

»A za to što me je snalazilo i skobilo nije bila dovoljna samo razboritost: ponekad su u nama - barem nekima - jači unutarnji porivi, osjećanja, potrebe ispunjenja neke dužnosti, unatoč svemu. (...) Sve da i nisam bio sustavni dio svijeta u kojem je ideja slobode duboko ukotvljena, vjerojatno bi isto tako bio prožet težnjom istobitnom... Ponetko je za to genetski - biološki programiran!

\footnotetext{
${ }^{43}$ Isto.

${ }^{44}$ Ivan Rukavina (1912.-1992.), partizanski zapovjednik, narodni heroj Jugoslavije, general armije JNA i zastupnik u Saveznoj skupštini SFRJ.

${ }^{45}$ Većeslav Holjevac (1917.-1970.), jedan od organizatora partizanskog ustanka u Hrvatskoj, general-potpukovnik JNA, gradonačelnik Zagreba.

${ }^{46}$ Nikola Kaić (1902.-1987.), partizanski zapovjednik i general-potpukovnik JNA.

${ }^{47}$ Ivan Šibl (1917.-1989.) partizan, narodni heroj Jugoslavije, general-potpukovnik JNA, član CK SK Hrvatske.

${ }^{48}$ Tuđman, Osobni dnevnik. 1973.-1989., knj. II., 262-263.

${ }^{49}$ Isto, 262.
} 
(...) Iznositi povijesne istine ljudima koji od kratkoročne slasti na vlasti ne vide ni prst pred nosom (...) Iskreno, bio sam od toga prečesto preumoran i prezabrinut, a ipak nisam mogao odustati (...) Čovjek čini uvijek ono što mora. Pa makar trenutačno i nemao sugovornika. ${ }^{50}$

Svoju trenutnu situaciju Tuđman dovodi u vezu i s posebnim darom koji posjeduje. Naglašava svoju posebnost i nesvakidašnjost.

U istoj toj bilješci Tuđman očituje i življenje za svoju stvar i slijeđenje svog djela kazujući: »Čovjek čini uvijek ono što mora. Pa makar trenutačno i nemao sugovornika.« Na 305. dan svojeg boravka u zatvoru (12. studenoga 1982.), zapisuje u dnevnik:

»Poniženja za plemenite ciljeve, našla su uvijek svoje uzvišenje, kao što su i uzvišenja zlom stizala na pravo mjesto. Sve sumnje i dvojbe, što mi ne daju mira ni danju niti noću, konačno se mire u još većoj odlučnosti. Uvrede što dolaze iz neznanja i gluposti - bole također, ali stradanja što su posljedak hrvanja sa silama zla - osnažuju životne sile s ove i one strane tamničkih zidina. Bez tragičnih zapleta nema rješenja drame. Bez društvenih kriza - nema kretanja. Plaćam, i koliko ću još morati i moći izdržati, kao što su i toliki drugi, koji se posvetiše ljepoti istine i slobode. Vrijednost čina ostaje bez obzira na trenutačan ishod. Objava istine u mraku, postaje još istinitija u svjetlosti. « ${ }^{51}$

Tuđman ovim riječima odlučno iskazuje življenje za svoju stvar i slijeđenje svog djela. Potaknut viješću o odluci Predsjedništva SFRJ o pomilovanju koje ga je zaobišlo, na svoj 388. dan u zatvoru (3. veljače 1983.) piše u dnevnik:

»Zaokupljen svim bićem, što će reći i srcem i umom - zadaćom svog življenja, čovjek je prepušten silama kojekakvim, idući za svojim idejama i onda kad se one sve više udaljuju kao puste tlapnje. Ali da u tome nema nekog unutarnjeg - podsvjesnog - pregnuća, moglo bi reći neutažive ljubavi prema svojoj zadaći, vjera u uspravnost tvog puta ishlapjela bi u burama nedaća. Život bi se istočio u pustopašnost. Ispraznost. Uzalud se čovjek pita: ne činim li puku ludost, posvećujući se čitav hiru znanosti i himbu slobode? Jamačno, poziv kojemu se čovjek preda po zakonima nekih unutarnjih poriva, odraz je strasti što je nezavisno od ljudske volje. (...) Zar ti nisu poznate sudbe proroka i pravednika? Da, ali mora se - i kad ne znamo po kojim to zakonima - ostati dosljedan sebi i onda kad se nema pravog protivnika, niti poštena sebi ravna subesjednika. (...) Kao proganjani nesretnik, čovjek je svjestan da osiljeno zlo besmisla uništava njegovo dosadašnje djelo i sprječava njegov nastanak danas, ali se daje voditi mišlju da prave vrijednosti moraju dati ploda, makar to bilo i sutra, ili makar bile trenutačno zatrpane i ruševinama, njihova će vrijednost jednom biti veća. I tako čuvamo svoju zemlju snova - usprkos svemu - a naša se misao oplođuje u beskraju budućih življenja. (...) I u grču očaja smijemo se udarcima sudbine, znajući da zločin sile može i zgromiti bolesnika, ali ne i izbjeći kobi zla, jer u pustolovini povijesti duh je ipak trijumfirao nad svim nakaznostima. (...) Uvjerenost $\mathrm{u}$ ispravnost puta. $\ll^{52}$

\footnotetext{
${ }^{50}$ Isto, 268.

${ }^{51}$ Isto, 342.

${ }^{52}$ Isto, 378.
} 
Tuđman iskazuje vjeru u vlastitu misiju govoreći o potpunoj zaokupljenosti »zadaćom svog življenja«, spominjući »poziv kojemu se čovjek preda po zakonima nekih unutarnjih poriva« i podsjećajući se na »sudbe proroka i pravednika.$^{53}$ Unatoč nepovoljnom razvoju situacije Tuđman iskazuje odlučnost da nastavi živjeti za svoju stvar i slijedi svoje djelo.

$\mathrm{Na}$ 389. zatvorski dan (4. veljače 1983.) zapisuje u dnevnik:

»Od Aretina do Voltairea i dalje - pisci su uvijek zadavali mučne brige svojim vladateljima. U povijesti pak ostaju dulje i više u životu pisac knjige negoli kojekakvi vlastodršci. Rijetki povjesničari su ujedno i pravi pisci. Prečesto samo - registratori. Samo neki imaju dara ili talenta da shvate bit povijesnih zbivanja, da sažmu i izraze duh svoga naroda i svoga doba.. ${ }^{54}$

Poistovjećujući se s piscima koji su kritizirali vlast i zbog toga bili zabranjivani i progonjeni, Tuđman upućuje na njihovu (i svoju) trajnu vrijednost i iznimnost ističući da »samo neki imaju dara ili talenta da shvate bit povijesnih zbivanja, da sažmu i izraze duh svoga naroda i svoga doba«. ${ }^{55}$

Nakon 13 i pol mjeseci provedenih u KPD Lepoglava, Tuđmanu je 23. veljače 1983. odobren prekid izdržavanja kazne zbog narušena zdravstvenog stanja. Nakon što mu je nekoliko puta bio produžavan prekid izdržavanja kazne, naposljetku se 26. svibnja 1984. morao javiti na izdržavanje kazne u zatvorsku bolnicu u Zagrebu. Na 41. dan boravka u zatvorskoj bolnici (5. srpnja 1984.) on piše u dnevnik:

»Pripadam narodu u kojem su svakog uništili tko se pokušao osoviti na vlastite noge (od Zrinskog i Frankopana pa nadalje na političkom području, a na intelektualnom, recimo od Filipa Grabovca, koji je zaglavio u mletačkim tamnicama, pa do Šufflaya, koga ubiše na zagrebačkoj ulici motkom, ili Ive Pilara (Sudland) koga su ubili ili natjerali u smrt, nakon što mu je druga knjiga (prva Južnoslavensko pitanje, u doba I. svjetskog rata) o hrvatskom pitanju izašla u inozemstvu (u doba šestosiječanjske diktature). Sve to znadoh, ali ipak drukčije nisam mogao. Niti mogu sada. Možda je u tome zalog opstojnosti i hrvatskog naroda kao i tolikih drugih u sličnom položaju. «56

Povezujući sebe i svoje djelovanje s junacima i intelektualcima iz hrvatske povijesti te njihovim djelovanjem i tragičnim sudbinama, Tuđman još jednom iskazuje usmjerenost svoje misije na jednu skupinu ljudi. Prema Tuđmanu, njegova misija je mogući »zalog opstojnosti i hrvatskog naroda i tolikih drugih u sličnom položaju巛. ${ }^{57}$

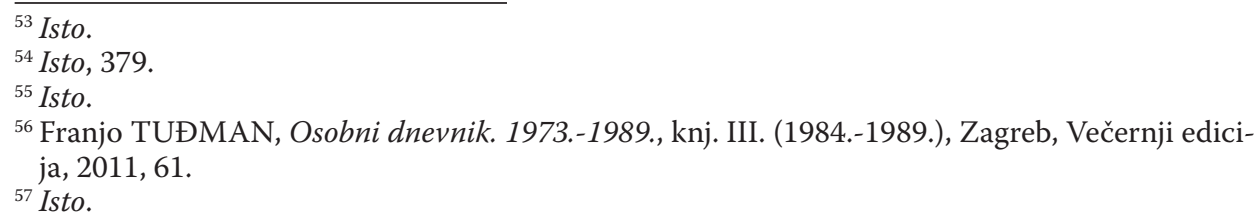




\section{Zaključak}

U analiziranom razdoblju od 1982. do 1984. Franjo Tuđman je nepobitno počeo iskazivati konstitutivna obilježja karizme - uvjerenje o posjedovanju posebnog dara te življenje za svoju stvar i slijeđenje svog djela. Analiza odabranih dnevničkih zapisa pokazuje da se smatrao osobom koja ima kvalitete koje uglavnom nisu dostupne drugima, pri čemu se posebno ističe njegovo shvaćanje sebe kao jedne od rijetkih osoba koja ima »dara ili talenta da shvati bit povijesnih zbivanja, da sažme i izrazi duh svoga naroda i svoga doba «. ${ }^{58}$ Ovo Tuđmanovo uvjerenje je posebno zanimljivo ako se zna da karizmatsko vodstvo može proisteći i iz vjerovanja da je vođa jedini kvalificiran razumjeti dijalektiku ili zakone povijesti i tako oživotvoriti budućnost. ${ }^{59}$ Analiza dnevničkih bilješki pokazuje i Tuđmanovu odlučnost da živi za svoju stvar i ide za svojim djelom usprkos zatvorskoj kazni, nerazumijevanju okoline i izostanku prave podrške. Bez obzira na trenutačne probleme i ograničenja Tuđman je spreman nastaviti svoju borbu vođen mišlju da »prave vrijednosti moraju dati ploda, makar to bilo i sutra«. ${ }^{60}$

Iz analize dnevničkih zapisa razvidno je i da Tuđman iskazuje konstitutivna obilježja čiste karizme - vjerovanje u vlastitu misiju i usmjerenost te iste misije na određenu skupinu ljudi. Tuđman je uvjeren u predodređenost svoje životne sudbine i posebnu ulogu koja mu je suđena $\mathrm{u} »$ misteriju povijesti«. U kontekstu Tuđmanove uvjerenosti u vlastitu misiju posebno je zanimljivo njegovo podsjećanje samog sebe na sudbinu proroka. Naime, prorok je, prema Maxu Weberu, »čisto osobni« nositelj karizme koji snagom svoje misije naviješta neki religiozni nauk ili pak neku božansku zapovijed. ${ }^{61}$ Tuđmanova misija usmjerena je na hrvatski narod i proizlazi iz potrebe da se »izgnaju magle s hrvatskog tla i pohrvate hrvatska obzorja u najplemenitijem smislu $\varkappa^{62}$ i tako ostvari nacionalna sloboda.

Karizmatski status neke osobe ovisi prvenstveno o sljedbenicima, a ne o $»$ karizmatiku« ${ }^{63}$ Sukladno tome, ni Franju Tuđmana nije moguće proglasiti karizmatskom osobom bez analize njegova odnosa sa sljedbenicima. No iz ove analize njegovih dnevničkih zapisa, razvidno je da je Tuđman u razdoblju prije dolaska na dužnosti predsjednika HDZ-a i predsjednika Republike Hrvatske pokazivao obilježja karizmatske osobnosti. Tuđmanova uvjerenost u posjedovanje posebnog dara, življenje za svoju stvar i slijeđenje svog djela

\footnotetext{
${ }^{58}$ Tuđman, Osobni dnevnik. 1973.-1989., knj. II, 379.

${ }^{59}$ Usp. Bensman, Givant, Charisma and Modernity..., 596.

${ }^{60}$ Tuđman, Osobni dnevnik. 1973.-1989., knj. II, 378.

${ }^{61}$ Usp. Blažević, Karizma..., 53.

${ }^{62}$ Tuđman, Osobni dnevnik. 1973.-1989., knj. II, 263.

${ }^{63}$ Usp. Keith GRINT, Social - Constructionist Analysis, u: R.A.W. RHODES i Paul T'HART (ur.), The Oxford Handbook of Political Leadership, Oxford, Oxford University Press, 2014, 240-252, 244.
} 
unatoč trenutačnim problemima i ograničenjima te vjerovanje u vlastitu misiju i usmjerenost te misije na hrvatski narod, bile su bitne pretpostavke uspješnog razvoja Tuđmanova karizmatskog vodstva unutar HDZ-a i širokog nacionalnog pokreta za stvaranje samostalne hrvatske države.

\author{
Jakov Žižić" \\ The Charismatic Features of Franjo Tudman: \\ Analyses of Diary Notes (1982 - 1984) \\ Summary
}

The article examines presence of the charismatic features on the case of Franjo Tuđman before he achieved the offices of President of Croatian Democratic Union and Republic of Croatia. Author analyse Tuđman's diary notes written during his prison period from 1982 to 1984 and examines did Tuđman in that period express core features of charisma - belief in the possession of specific gift and living for his cause and striving to create his work. The analyses of diary notes also examines did Tuđman express core features of pure charisma - belief in his own mission and aiming of his mission on the certain group of people. The analysis showed that during the observed period Tuđman expressed charismatic features that will be of great importance for successful development of his charismatic leadership in the beginning of 1990s.

Key words: Franjo Tudman, charisma, Croatian Democratic Union, personal diary.

(na engl. prev. Jakov Žižić)

\footnotetext{
" Jakov Žižić, M.A. in Political Science and PhD Candidate in Comparative Politics at the Faculty of Political Sciences, University of Zagreb; Assistant at Catholic University of Croatia; Address: Ilica 242, HR-10000 Zagreb, Croatia; E-mail: jakov.zizic@unicath.hr.
} 